Recibido: 22 de junio de 2020

Evaluación: 15 de julio de 2021

Aprobado: 30 de julio de 2021

Artículo de investigación (C) 2021 Universidad Católica de Colombia. Facultad de Ciencias Económicas y Administrativas. Todos los derechos reservados

"PhD in Applied Economics, Institute of Social Sciences, University of Lisbon, Lisbon, Portugal, E-mail: felippe.clemente@ics.ulisboa.pt (D) https://orcid.org//0000-0003-3465-9711

\section{Analysis of the Brazilian tax incentives to innovation and patent data: a Principal-Agent model approach}

\begin{abstract}
We propose to evaluate Lei do Bem (law 11.196/05) for Brazilian regions (North, Northeast, Center-West, Southeast and South). This is the first study that analyzes Lei do Bem using extensive game simulations for the different regions of the country. Based on data from 2006 to 2015, we find moral hazard between government and innovative Brazilian companies, as there was no express incentive in the Lei do Bem to stimulate the industrial sector to innovate and register the innovation as a patent. Thus, policies that review the tax incentives structure contained in the Lei do Bem as well as encourage industries and companies to file patents in public patent databases may have positive effects on the Brazilian innovation system.
\end{abstract}

Keywords: Lei do Bem, innovation, patent data, Principal-Agent model.

JEL Classification: D01, D34, O30 


\section{Análisis de los incentivos fiscales brasileños a la innovación y los datos de patentes: un enfoque desde el modelo del agente-principal}

\section{Resumen}

Nos proponemos evaluar la Lei do Bem (ley 11.196/05) para las regiones brasileñas (Norte, Nordeste, Centro-Oeste, Sudeste y Sur). Este es el primer estudio que analiza la Lei do Bem utilizando simulaciones de juegos extensos para las diferentes regiones del país. A partir de los datos de 2006 a 2015, encontramos riesgo moral entre el gobierno y las empresas innovadoras brasileñas, ya que no había ningún incentivo expreso en la Lei do Bem para estimular al sector industrial a innovar y registrar la innovación como patente. Por lo tanto, las políticas que revisan la estructura de incentivos fiscales contenida en la Lei do Bem, así como el estímulo a las industrias y empresas para registrar patentes en las bases de datos de patentes públicas, pueden tener efectos positivos en el sistema de innovación brasileño.

Palabras clave: Lei do Bem, innovación, datos de patentes, Modelo de Agente-Principal. 
Analysis of the Brazilian tax incentives to innovation and patent data: a Principal-Agent model approach

\section{INTRODUCTION}

In recent years, incentives for innovation in the form of tax incentives have become an international trend. Such countries, mainly more technologically advanced countries, namely Canada, the United States, France, and the United Kingdom, have used tax incentives to stimulate innovation and R\&D since the 1970s. These countries began discussing standardization of incentives for innovation with the Frascati Manual in 1963. ${ }^{1}$ The Manual was extremely important for understanding the role of science and technology in economic development. The definitions set out therein are internationally accepted to this day, and set a common language for discussion of scientific and technological policies, as well as standardizing incentive mechanisms to encourage investment and execution of R\&D activities, such as fiscal incentives (Barbosa et al., 2013).

Although far from perfect, these incentives have some advantages that make them attractive to policymakers: (i) they are based on market allocations, as the decision-making process regarding the development of innovation and the amount of expenditure is firm; ii) do not discriminate between sectors; and iii) are readily available to companies, with low administrative costs for the government. (CORDER, 2006).

In this context, according to Clemente and da Silva (2017), Brazil belatedly reformulated in 2004 and 2005 its institutional apparatus for innovation, to approach OECD conventions and the Frascati Manual. The Innovation Law (2004) and the Lei do Bem (2005) reduced some institutional barriers to innovation, provided incentives for university-business cooperation, and modified access to tax incentives for innovation. Chapter III of the Lei do Bem (Law No.11.196/05) is currently the most comprehensive tax incentive stimulating innovation. It complies with the determination of the Innovation Law (Law 10.973/04), which establishes that the Government should foster innovation in companies or industries by granting tax incentives. The law simplified the bureaucratic procedure by not requiring pre-approval of projects or participation in bidding processes (Zucoloto, 2008). As a result, when the law came into effect, in 2006, 130 firms used tax incentives for innovation, 320 in 2007 and 552 in 2008. Although this number is on the rise, it is still small, if we consider there are around six thousand firms conducting research and development (R\&D) activities in Brazil (Araújo, 2009).

1 OECD Expert met with the NESTI (National Experts on Science and Technology Indicators) group in the city of Frascati, Italy, presenting as a result of their work the first version of the Frascati Manual, known as "The Proposed Standard Practice for Surveys of Research and Experimental Development", aiming to standardize the methodology for the development of Research and Development. 
However, according to Zucoloto (2008), the Lei do Bem has some obstacles. One of these is in the percentages of tax incentives provided to companies. These percentages reveal a significant sectorial correlation between R\&D expenditure by large companies and R\&D expenditure of companies that accessed the Lei do Bem, achieving a correlation of $95.8 \%$ in 2008 . These results are important in investigating the Law's ability to stimulate private R\&D investment. Preliminary analysis suggests that this instrument has not yet been able to stimulate sector diversification of these investments in Brazil, as its benefits are mostly captured by sectors that already carried out this activity. One of the causes may be the existence of moral hazard ${ }^{2}$ between the government and beneficiaries of the Lei do Bem. Moral hazard applies to behavior after the institutionalization of law, in which a party has private information which it can use to take advantage of the prejudice of the other party.

Several studies indicate that the Lei do Bem is a promising instrument since the number of companies and incentive volume has increased since its creation. However, they only concentrated in the post-concessionary relations of the incentives, both by public agents, who cannot control how the use of tax benefits occurs, but also by the private sector, which is not encouraged to expend much effort in the phenomenon of innovation.

Thus, the purpose of assessing the presence of moral hazard regarding the Lei do Bem, from 2006 to 2015, period that the law was in effect, using the theoretical approach known as Principal-Agent ${ }^{3}$ arises. This procedure has been a recurring theme abroad since the early 1980s but has little approached in Brazil. Studies involving this approach are becoming increasingly important since it reduces the asymmetry of information that exists in the most diverse businesses.

Within the scope of the Brazilian innovation system, we are not aware of any studies that show the presence of a moral hazard or opportunistic behavior on the part of the beneficiary companies. We know that there are distortions between the real purpose of the law and its application, which encourages us to investigate the

2 The concept of moral hazard refers to the possibility of an agent changing its behavior according to the different contexts after the establishment of a rule or a law. That is asymmetric information, a situation in which one party in the transaction has more information than the other. The principal-agent problem is a special case of moral hazard, in which one party, the agent, acts in the interest of the other party, the principal. The agent may have an incentive or tendency to act inappropriately from the principal's point of view if the interests of the agent and principal are not aligned. The agent usually has more information about his actions or intentions than the principal, because the principal usually cannot perfectly monitor the agent (Clemente and Silva Júnior, 2012).

3 The Principal-Agent problem is characterized by a Principal inducing (using a legislative act) an Agent to follow certain rules. The problem of the Principal is to designate, under the law, a "pay-off" that encourages the Agent to act in the best possible way (MAS-COLELL, 1995). 
causes of such distortions. This study, then, is pioneering in evaluating the presence of moral hazard in the Lei do Bem from the perspective of the Principal-Agent model.

To measure the impact of tax incentives on innovation by companies that have accessed the Lei do Bem, we used the patents database ${ }^{4}$ by the National Institute of Intellectual Property (INPI). Patent statistics, even in countries with well-established databases such as the United States, have countless limitations as indicators of technological activities (Albuquerque, 1996). Cohen \& Levin (1989) stress how "the economic value of patents is highly heterogeneous" (p.1063). Despite these and other limitations, Griliches (1990) completed a comprehensive "survey" on the subject stating that "despite all the difficulties, patent statistics remains a unique and solid source for analyzing the process of technological change" (p.1702). Other researchers analyzed several other mechanisms used to measure the impact of tax incentives on innovation activities. (Freeman, 1982; Andersen et al., 2002; Tether, 2003; Kannebley Júnior et al, 2016; Blind et al, 2018).

In the case of Brazil, the alternative database to the patent bank is the National Survey of Innovation (PINTEC) by the Brazilian Institute of Geography and Statistics (IBGE). However, there are also countless limitations which, for this study, are impracticable, especially the main ones: i) the research is triennial, which limits the evaluation of the Lei do Bem from year to year; and ii) in PINTEC, companies do not declare individual access to the benefits offered by the Lei do Bem, which makes it impossible to extract the object of this research (companies benefitting from the Lei do Bem from 2006 to 2015) from the database. Thus, the filing of patents per company as a proxy for innovation is more appropriate to the study.

This article has four sections. In addition to this introduction, we present the theoretical framework followed by the methodology and source of the data, as well as the results, discussions, and final considerations.

\section{THEORETICAL FRAMEWORK}

Schwartz (1992) observes that public or private instruments (contracts, equivalent documents, laws, legislative acts, etc.) are inevitably incomplete when one of the

4 A patent is a title of ownership over an invention or utility model, it may be a product or process. This title grants to the inventors the rights of the creation, to protect the products or the process, in which time and resources were invested, against the copy or commercialization of the holder's authorization (Pereira, 2003). 
Felippe Clemente

parties has a condition or information that is not observable by one or both parties, or a non-verified condition "ex-post".

It is noteworthy that, according to the literature, these instruments are incomplete due to the presence of uncertainty (limitation in predicting all future conditions in a relationship) and opportunism.

Uncertainty occurs because, no matter how much the human being tries to do their best, because of cognitive limitations, they will not achieve this. Opportunism, however, occurs due to the predisposition of individuals to maximize their utility (NASCIMENTO, 2007).

Thus, the instruments of interest deal with two types of situations: adverse selection (opportunistic behavior before the instruments) and moral hazard (opportunistic behavior after the instruments). These phenomena may affect the right of the results sought by the parties involved in the transaction (COSTA, 2008).

According to Salainié (2002), moral hazard is an information problem, lack of alignment of interests, different levels of knowledge for delegation, and difficulties to observe the levels of effort of economic agents. Varian (1999) establishes that moral hazard is due to the lack of economic incentives.

And one way to evidence the presence of moral hazard is by using the concepts of the principal-agent theory. Thus, both the principal and the agent take this behaviour (LAFFONT, 2002).

Varian (1999) points out that to alleviate the problems of moral hazard between the agents and the principal, one must monitor their activities and establish economic incentives. The principal should monitor based on proxies that objectively present the level of effort of the agent. Incentives should encourage the agent to act in a manner close to what was established in the negotiation. To understand the problem of moral hazard it is necessary to study Principal-Agent modeling. Thus, the Principal wants to choose a function(s) that maximizes its utility, subject to the constraints imposed by the Agent's optimization behavior, of which there are two: i) Participation Restriction (RP) ${ }^{5}$ and Incentive Compatibility (RCI) ${ }^{6}$ (SAMPAIO, 2007).

5 Represents the Agent's decision to agree whether or not to follow the law proposed by the Principal, according to its level of utility

6 The Principal offers an incentive scheme capable of inducing the Agent to choose to act as it wishes. 
According to Clemente and Silva Júnior (2013), based on Laffont (2002), the general formulation of the Principal-Agent is for two players, considers A= set of actions by the agent; $\mathrm{S}=$ set of possible results. The agent takes actions "a" belonging to set, $A=\{a 1, a 2, \ldots, a N\}$ which produces a result "s" of set $S=\{s 1, s 2, \ldots, s M\}$ and occur with a specific probability: $\pi \mathrm{n} 1, \pi \mathrm{n} 2, \ldots, \pi \mathrm{nM}$, so that $\sum_{m=1}^{M} \pi_{n m}=1$.

Thus, for each action "a" belonging to set $\mathrm{A}$, we have a probability distribution $\prod A$ in $S$. If $w$ is the value paid for the service, we assume that $w$ is a function $w$ : $\mathrm{S} \rightarrow \mathrm{R}$. This is , if "s" is observed, the principal pays w(s) to the agent, i.e., the agent's compensation is determined by the result of its actions.

For the principal, a pair of "a" and "s" results in an income B $(\mathrm{a}, \mathrm{s})$ and, consequently, the principal's profits are given by: $B(a, s)-W(s)$. Thus, the expected profits of the principal can be written as:

$$
\text { Expected return }=\sum_{m=1}^{M} \pi_{n m}\left(B\left(a_{n}, s_{m}\right)-W\left(s_{m}\right)\right)
$$

The profit of the principal is the result produced by the agent's action less what is paid to the agent for the services rendered.

For the agent, a Von Neumann-Morgenstern utility function, $\mathrm{u}(\mathrm{w}, \mathrm{a})$, is assumed. Considering that each agent has other alternatives that provide it with its utility reserve, it agrees to participate in the negotiation proposed by the principal if the inequation (2) is verified:

$$
\text { Expected utility }=\sum_{m=1}^{M} \pi_{n m} u\left(w\left(s_{m}\right), a_{n}\right) \geq \bar{u}
$$

That is, participation restriction (RP) is satisfied when its expected utility of the chosen action $(a n)$ is greater than or equal to the expected utility of the other available actions.

In addition, the principal induces the agent to take action that maximizes its expected profits, satisfying the incentive compatibility constraint (RCI). For the chosen action an:

$$
\sum_{m=1}^{M} \pi_{n m} u\left(w\left(s_{m}\right)-d\left(a_{n}\right) \geq \sum_{m=1}^{M} \pi_{n^{\prime} m} u\left(w\left(s_{m}\right)\right)-d\left(a_{n^{\prime}}\right)\right.
$$

in which

$\mathrm{n}^{\prime}=1 \ldots \mathrm{N}$

$\mathrm{d}$ is the wear or disutility resulting from the execution of an action. 
Thus, for each w and each an action, we have a payoff (pair of results for the principal and agent, respectively) of:

$$
\sum_{m=1}^{M} \pi_{n m}\left(B\left(a_{n}, s_{m}\right)-W\left(s_{m}\right)\right) ; \sum_{m=1}^{M} \pi_{n m} u\left(w\left(s_{m}\right), a_{n}\right) \geq \bar{u}
$$

Figure 1 shows how to solve this game by means of balancing in Perfect Subgame, that is, solving the game from back to front. In the last stage, the agent chooses its action an, in order to respect the RCI; then it is observed whether its utility is greater than its expected utility (RP; finally, the negotiation that the principal proposes [the pair w(s) and s] given the agent's choices, so that the principal's revenue is maximized).

Figure 1. General form of a Principal-Agent game

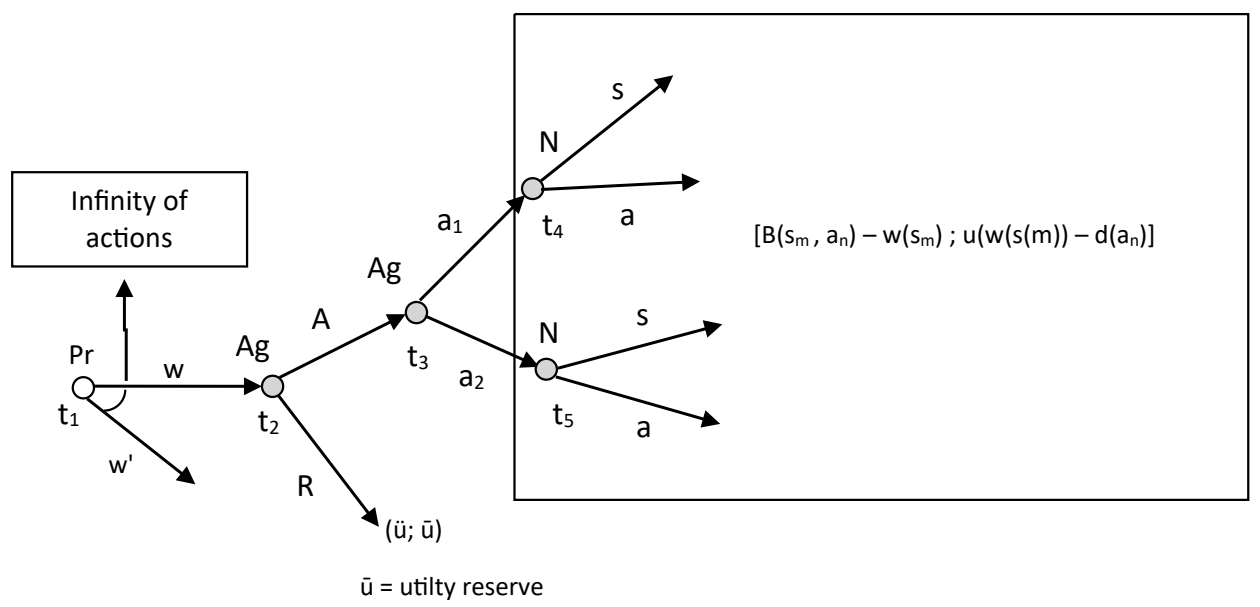

Source: SAMPAIO (2007).

According to Hall and Lerner (2009), within the R\&D setting, the deviated data issue alludes to the truth that an innovator as often as possible has superior data approximately the probability of victory and the nature of the mulled over development extend than potential financial specialists. Hence, the commercial center for financing the advancement of innovative ideas looks just like the "lemons" showcase (Akerlof, 1970). The 'lemons' premium for R\&D will be higher than that for conventional speculation since financial specialists have more trouble recognizing great ventures from terrible when the ventures are long-term R\&D speculations than when they are more short-term or low-risk ventures (Leland \& Pyle, 1977). 
When the level of R\&D consumption could be an exceedingly discernible flag, because it is beneath current U.S. and U.K. rules, we might anticipate that the lemons' issue is to some degree moderated, but certainly not disposed of (Bhattacharya \& Ritter, 1983; Anton \& Yao, 2002). In this way the suggestion of hilter kilter data coupled with the expensiveness of mitigating the issue is that firms and creators will confront a better taken a toll of outside than inner capital for R\&D due to the lemons' premium.

A few experimental bolster for this suggestion exists, generally within the shape of occasion considers that degree the advertise reaction to declarations of unused obligation or share issues (see: Jensen \& Meckling, 1976; Cho, 1992; Francis \& Smith, 1995; Johnston \& Rao, 1997; Majumdar \& Nagarajan, 1997; Pugh, Jahara, \& Oswald, 1999; Eng \& Shackell, 2001). Both Alam \& Walton (1995) and Zantout (1997) discover higher irregular returns to firm offers taking after modern obligation issues when the firm is more R\&D-intensive. The contention is that the procurement of unused sources of financing is nice news when the firm has a hilter kilter data issue since of its R\&D technique. So also, Szewcxyk, Tsetsekos, \& Zantout (1996) discover that speculation opportunities explain R\&D-associated irregular returns which these returns are higher when the firm is exceedingly utilized, inferring a better required rate of return for obligation back in harmony.

In spite of the fact that the prove summarized over is decently clear and shows that long term motivations for supervisors can empower R\&D which organization possession does not essentially dishearten $R \& D$ speculation, it is decently noiseless on the size of these impacts, and whether these administration highlights really near the office cost-induced crevice between the fetched of capital and the return to R\&D.

\section{LEI DO BEM}

Until the introduction of the Lei do Bem, the policy of tax incentives for innovation followed the provisions of Law 8.661/93, which represented the resumption of the mechanism a technological policy instrument in Brazil. The obtaining of tax incentives was conditional on the execution of Industrial and Agricultural Technological Development Programs (PDTI and PDTA) by the companies.

7 The explanations about the Lei do Bem and its consequences were taken from the text by Araújo (2009), called Tax Incentives for Research and Development and Innovation Costs in Brazil, due to its excellent and competent synthesis, as well as the robust explanation of the tax incentives offered by such law. 
Felippe Clemente

In this line, the Ministry of Science and Technology or federal and state agencies and entities for technological development or research that are accredited by the Ministry for the exercise of this assignment should approve PDTIs and PDTAs. The complexity of these forms was considered one of the main obstacles to the use of the instrument (MATESCO and TAFNER, 1996).

In 1997, the incentives of Law 8.661/93 changed, essentially related to a significant reduction of the percentages involved. Subsequently, modifications included the authorization of granting an economic subsidy to companies engaged in said programs (Law 10.322/01) and, at the same time, the extension of existing incentives (Law 10.637/02).

The changes brought by the Lei do Bem (Law No.11.196/05) made the use of tax incentives much simpler and more direct. As a result, more firms began to use them, especially due to eliminating the need for prior authorization.

The main change introduced by the Lei do Bem was the deductibility of R\&D expenses at the ratio of 1.6 of the tax base, eliminating the tax credit-based mechanism. With this, the Lei do Bem ended any kind of restriction on the usufruct of tax credits.

The following are the three incentives related to income taxes introduced by the Lei do Bem:

i. Current spending on R\&D activities could be deducted from the IRPJ (Legal Entity Income Tax) and CSLL (Social Contribution on Net Income) taxes base at the rate of $160 \%$. This rate increases by $20 \%$ if the company raises the number of researchers by more than $5 \%$, and increases by $10 \%$ if the company raises the number of researchers by up to $5 \%$. The rate could also be increased by $20 \%$ if the firm had a patent granted. However, since the average time between application for registration and the granting of a patent is eight years, patents end up being related to past technological efforts

ii. As with the PDTI and PDTA, the rate of depreciation of investments in machinery and equipment for innovation could be accelerated in two parts, but only for purposes of IRPJ

iii. Intangible assets related to technological activities would be fully amortized in the year of purchase, but also only for IRPJ purposes. 
Analysis of the Brazilian tax incentives to innovation and patent data: a Principal-Agent model approach

In addition to these new incentives related to the tax base for IRPJ and CSLL, the Lei do Bem included other mechanisms, such as:

- 50\% reduction of IPI (Tax on Manufactured Products) for capital goods to be used for innovation;

- IRPJ tax credit of $20 \%$ on international remittances related to royalties and technical assistance for expenditure up to December 2008, and 10\% for expenses incurred after this date

- Elimination of taxes levied on international consignments relating to patent and trademark registrations; and

- Subsidy of $40 \%$ of the payroll of full-time researchers - this subsidy can reach $60 \%$ for companies located in the North and Northeast regions

In 2008 there was a revision of the Lei do Bem, and the main change occurred in the rule of depreciation. From that year on, the companies were able to fully depreciate in the year in which the investments in machinery and equipment for technological development were made, and this permission became applicable also to the CSLL.

The law defines innovation based on the Oslo Manual concept, but the definition of expenditure on innovation is very broadly. It includes not only in-house $R \& D$, but also contracted R\&D by companies and universities, as well as royalties and technical assistance expenses.

The Lei do Bem incentives, global in character, do not have incremental rules or incentives. The result of the changes introduced by the Lei do Bem was that more firms started to use innovation tax incentive mechanisms in Brazil.

However, considering that there are around six thousand companies with R\&D activities in Brazil and that only 1,205 accessed Lei do Bem incentives in 2015, there is a great potential for the use of these incentives in Brazil, as they become more widely known and effective. Besides, we could observe that there was no precise criticism of the Lei do Bem. This means the Lei do Bem supports only product innovations, processes, and services (technological innovations), not considering organizational and marketing innovations. The Lei do Bem doesn't make satisfactory differentiation between radical and incremental innovations which may be a serious problem for developing countries, such as Brazil. 
Felippe Clemente

\section{METHODOLOGY}

To evaluate the tax incentives of the Lei do Bem, we based the methodology of this study on the Principal-Agent model, as presented above.

In the scope of innovation, incentives to agents can be of the most diverse sort; for example, tax exemptions or subsidies, depending on the type of activity that the law regulates. Table 1 shows the main tax incentives for $\mathrm{R} \& \mathrm{D}$ activities, defined based on the Frascati Manual of developed countries: Canada, the United States, France, and the United Kingdom. In the Table, we can see the potential of the innovation support instrument known as a tax incentive, as countries with a high technological base exempt companies that invest in R\&D from more taxes.

Concerning the Lei do Bem, there are countless incentives and stimuli for innovation: i) additional deduction of $60 \%$ of Legal Entity Income Tax (IRPJ); ii) deduction of $20 \%$ for a patent granted; iii) full depreciation in the year of acquisition of equipment and accelerated amortization for intangible assets; iv) reduction of IPI of up to $50 \%$ in the acquisition of equipment. Given these incentives, the agents can make a specific level of effort, low or high, and this decision impacts the final result. In addition, the agent is still subject to random factors, which can positively (good luck) or negatively (bad luck) influence the outcome.

In the context of the Lei do Bem, companies, and industries are seen as "Agent" and the government is seen as "Principal". Since the law has specific points to be fulfilled by the Agents, then there is a Principal-Agent problem with covert actions. This hypothesis is based on the observation that, even with all the inspection care that can be taken in the company's innovation department, he does not monitor at all times, and therefore, it is up to the Agent to decide whether to follow the rules laid down by law in full or in part.

Presenting different objectives within the principal-agent system, the problem is limited to the tax reward structure that the government proposes to the company. The government (Principal) wants an effective law that fulfills its purpose, which depends on the "effort" made by the company in the innovation sector, as well as on random factors (states of nature) such as economic crisis, technological change, etc. We know that companies and industries also present sectorial factors such as changes in production chains, the establishment of market power, etc. 
Analysis of the Brazilian tax incentives to innovation and patent data: a Principal-Agent model approach

Table 1.

Research and Development Incentive Policies

\begin{tabular}{|c|c|c|c|c|c|}
\hline Countries & Access & Benefit & Limits & Benefitiaries & Observations \\
\hline \multirow[b]{2}{*}{ Canada } & \multirow{2}{*}{$\begin{array}{l}\text { Government } \\
\text { Approval }\end{array}$} & $\begin{array}{l}35 \% \text { refundable tax } \\
\text { credit for micro and small } \\
\text { businesses; }\end{array}$ & \multirow{2}{*}{$\begin{array}{c}\text { No } \\
\text { limitation }\end{array}$} & \multirow{2}{*}{$\begin{array}{l}\text { Companies } \\
\text { of all sizes }\end{array}$} & $\begin{array}{l}\text { Tax credit valid for use for } \\
\text { up to } 20 \text { years. }\end{array}$ \\
\hline & & $\begin{array}{l}20 \% \text { non-refundable tax } \\
\text { credit for large companies. }\end{array}$ & & & $\begin{array}{l}\text { Expenses may be } \\
\text { accumulated for a period } \\
\text { of } 3 \text { years and the accrued } \\
\text { period of benefit. }\end{array}$ \\
\hline \multirow[b]{2}{*}{$\begin{array}{l}\text { United } \\
\text { States }\end{array}$} & \multirow[b]{2}{*}{ Automatic } & $\begin{array}{c}\text { Tax credit of } 20 \% \text { of } \\
\text { incremental expenses on } \\
\text { R\&D activities; }\end{array}$ & \multirow[b]{2}{*}{$\begin{array}{c}\text { No } \\
\text { limitation }\end{array}$} & \multirow[b]{2}{*}{$\begin{array}{l}\text { Companies } \\
\text { of all sizes }\end{array}$} & $\begin{array}{l}\text { Companies must meet a } \\
\text { preliminary test ( } 4 \text { part } \\
\text { Test). }\end{array}$ \\
\hline & & $\begin{array}{l}\text { 14\% Simple Alternative } \\
\text { Credit for Qualified } \\
\text { Research Expenditures - } \\
\text { QREs minus } 50 \% \text { of the } \\
\text { average research for the } \\
\text { last three fiscal years. }\end{array}$ & & & \\
\hline \multirow{3}{*}{ France } & \multirow{3}{*}{ Automatic } & $\begin{array}{c}\text { Tax credit of } 40 \% \text { of } \\
\text { expenses in the first year of } \\
\text { the benefit; }\end{array}$ & \multirow{3}{*}{$\begin{array}{c}\text { No } \\
\text { limitation }\end{array}$} & \multirow{3}{*}{$\begin{array}{l}\text { Companies } \\
\text { of all sizes }\end{array}$} & \multirow{3}{*}{$\begin{array}{l}\text { Accountability to be } \\
\text { delivered by } 3 \text { months and } \\
15 \text { days following the end } \\
\text { of the fiscal year. }\end{array}$} \\
\hline & & $\begin{array}{l}35 \% \text { tax credit in the } \\
\text { second year of the benefit }\end{array}$ & & & \\
\hline & & $\begin{array}{l}\text { Coming years, tax credit } \\
\text { of } 30 \% \text { of expenses up to } \\
100 \text { million euros, and } 5 \% \\
\text { on expenses above this } \\
\text { amount. }\end{array}$ & & & \\
\hline \multirow{3}{*}{$\begin{array}{l}\text { United } \\
\text { Kingdom }\end{array}$} & \multirow{3}{*}{ Automatic } & $\begin{array}{l}\text { Deduction of } 225 \% \\
\text { for micro and small } \\
\text { enterprises. }\end{array}$ & \multirow{3}{*}{$\begin{array}{c}\text { No } \\
\text { limitation }\end{array}$} & \multirow{3}{*}{$\begin{array}{l}\text { Companies } \\
\text { of all sizes }\end{array}$} & \multirow{3}{*}{$\begin{array}{l}\text { The time limit for using the } \\
\text { benefits is up to two years } \\
\text { after the end of the fiscal } \\
\text { year. }\end{array}$} \\
\hline & & $\begin{array}{l}130 \% \text { deduction for large } \\
\text { companies; }\end{array}$ & & & \\
\hline & & $\begin{array}{l}\text { Patent Box to reduce your } \\
\text { Corporation Tax on profits }{ }^{8}\end{array}$ & & & \\
\hline
\end{tabular}

Source: Prepared by the author based on Barbosa et al. (2013).

$\overline{8}$ See more: https://www.gov.uk/guidance/corporation-tax-the-patent-box 
However, for this research, we consider only random factors of macroeconomic origin, given the national scope of the database used. In addition, it is considered as a proxy for the effort expected by the government to file patents by companies that accessed the Lei do Bem in the period from 2006 to $2015 .{ }^{9}$

Thus, the timing of the game follows: the government promulgates a certain law, in this case, the Lei do Bem and discloses to companies that undertake innovation and R\&D. Each company then decides whether or not to participate in the law and decides whether to make a certain level of effort, in which case, to record innovation achieved through filing patents. Finally, they observe the state of nature, and so verify the equilibrium reached.

To facilitate visualization, in general, it is possible to enumerate the steps followed in the methodology:

i. Firstly, we analysed the Lei do Bem to verify at which points moral hazard may occur and where there is no economic incentive;

ii. After that, we designed simulations of possible games, using Lei do Bem incentives to innovation, taking into account the states of nature (good/ bad luck), which can influence its outcome positively or negatively

iii. Subsequently, we obtained the solution of the game using the perfect equilibrium in subgame, that is, solving the game from back to front;

iv. Finally, it analyses whether the Lei do Bem is free or not of the problem of moral hazard.

\section{Source of the data and variables}

We collected data from several sources: i) the financial volume renounced by the government for the benefit of Brazilian companies, the Lei do Bem reports from 2006 to 2015, published by the Ministry of Science, Technology, and Innovation (MCTI); ii) to select the companies that accessed the tax benefits in the period from 2006 to 2015 the annex of the Lei do Bem reports, which contain the National Register of Corporate Taxpayers Number (CNPJ) of the participating companies;

9 Several studies justify the proxy that analyses the impact of patent costs on innovation. The report of the European Commission for Innovation "Patent costs and impact on innovation" for the year 2016 contributes a complete survey on studies relating to patents and innovation. However, patent data as an ST\&I indicator has some limitations developed in the literature (KANNEBLEY JÚNIOR et al, 2016; BLIND et al, 2018). 
Analysis of the Brazilian tax incentives to innovation and patent data: a Principal-Agent model approach

and iii) to extract the patent filings of the companies benefited by the Lei do Bem on the public database of the National Institute of Intellectual Property (INPI).

The variables used in the simulations of the Principal-Agent model for the different Brazilian regions follow on Table 2:

Table 2.

\section{Variables and parameters used in the simulations}

\begin{tabular}{|c|c|}
\hline Variables & Parameters \\
\hline Company investment - high effort/good luck ${ }^{10}$ & 4.4 x incentives granted \\
\hline Company investment - high effort/bad luck ${ }^{11}$ & 3.83 x incentives granted \\
\hline Company investment- low effort/good luck & 4.4 x incentives granted \\
\hline Company investment- low effort/bad luck & 3.83 x incentives granted \\
\hline Government social cost & Value of waived taxes \\
\hline Cost of filing patents in Brazil 12 & $\mathrm{R} \$ 33,463.10 .^{13}$ \\
\hline Companies' utility reserve & $\mathrm{R} \$ 0$ \\
\hline Incentives for filing patents - SE & $\mathrm{R} \$ 5,268,453.42$ \\
\hline Incentives for filing patents $-\mathrm{S}$ & $\mathrm{R} \$ 974,091.11$ \\
\hline Incentives for filing patents $-\mathrm{NE}$ & $\mathrm{R} \$ 24,211.11$ \\
\hline
\end{tabular}

Source: Author's elaboration.

\section{RESULTS}

To evaluate the companies that accessed the Lei do Bem, as well as the patent filings, made, ${ }^{14}$ we carried out a descriptive analysis and, afterward, simulations with the Principal-Agent model.

\section{Descriptive analysis}

For the period between 2006 and 2015, companies accessed the Lei do Bem 5,932 times, in the form of tax incentives. In total, 2,021 companies received innovation

10 Multiplier effect of tax incentives to innovation. That is, every 1 real in incentives, companies invest 4.4 reais. Information available at: ANPEI, 2017.

11 Decline in investments in approximately $13 \%$ for periods of crisis, according to data from the Annual Industrial Survey of Companies (PIA-Empresas) of the Brazilian Institute of Geography and Statistics (IBGE), 2015.

12 See Kagan Binder, PLLC, 2004.

13 Cost in dollars: $\$ 10,490$ and the dollar exchange rate for July 14, 2017: $\mathrm{R} \$ 3.19$.

14 Patent data as an ST\&I indicator has some limitations developed in the literature (KANNEBLEY JÚNIOR et al, 2016; BLIND et al, 2018). 
benefits and accessed the law to obtain such incentives, on average, 2.54 times. Given the geographical, economic, and industrial diversity of Brazil, we carried out a specific analysis to ascertain access to tax incentives by companies from all regions of Brazil. In this research, we disregarded the sectorial question because there was no available patent bank in Brazil distributed according to the productive sector. The Southeast region $(1,225$ companies $)$ concentrates the largest number of companies that have obtained tax incentives for innovation through the Lei do Bem, followed by the South (652), Northeast (97), Midwest (38), and North (9). There is a strong concentration of beneficiary companies located in the South and Southeast regions $(92.87 \%)$ and an inexpressible share of the North region $(0.045 \%)$.

For the number of accesses ${ }^{15}$ to the Lei do Bem, we have: the Southeast region with 3,545 direct accesses to tax incentives; the South region with 1,976 accesses; the Northeast region with 212; the Midwest region with 83 and the North region with 27 accesses. Once again, there is a strong concentration of accesses in the South and Southeast regions of Brazil ( $95 \%$ of the total). Table 3 shows the average, by state, of accesses to the Lei do Bem by the beneficiary companies.

Table 3.

Average number of accesses, by State, to the Lei do Bem by companies in the period from 2006 to 2015

\begin{tabular}{|c|c|c|c|c|c|}
\hline \multicolumn{2}{|c|}{ South } & \multicolumn{2}{c|}{ Northeast } & \multicolumn{2}{c|}{ North } \\
\hline RS & 3.33 & MA & 4.00 & AM & 0.00 \\
\hline SC & 2.81 & PI & 0.00 & AC & 0.00 \\
\hline PR & 2.64 & CE & 2.21 & RR & 0.00 \\
\hline \multicolumn{2}{|c|}{ Southeast } & BA & 2.16 & RO & 1.00 \\
\hline SP & 2.91 & RN & 0.00 & PA & 2.80 \\
\hline RJ & 2.71 & PB & 2.40 & AP & 0.00 \\
\hline MG & 2.94 & PE & 2.13 & & \\
\hline ES & 3.82 & AL & 0.00 & & \\
\hline \multicolumn{2}{|r|}{ Midwest } & SE & 2.33 & & \\
\hline GO & 2.14 & TO & 2.50 & & \\
\hline MT & 2.20 & & & & \\
\hline MS & 1.50 & & & & \\
\hline DF & 2.40 & & & \\
\hline
\end{tabular}

Source: Author's elaboration.

15 The number of accesses is the number of years that companies have accessed the Lei do Bem to receive tax incentives for innovation. If, for example, a company accessed each year the law throughout the period analyzed (2006-2015) then we counted nine times. 
When verifying the number of patents filed by companies benefiting from the Lei do Bem, there is a significant reduction in numbers. In total, 489 companies filed an innovation patent in the period from 2006 to 2015 in the INPI patent bank, that is, only $24 \%$ of the total number of companies that received tax incentives in the same period patented some product or process innovation. According to Figure 2, the State of São Paulo had the largest number of companies that filed patents (215 in total) and had the highest number of accesses to the Lei do Bem (827 in total). The state with the second-largest number of companies was the Rio Grande do Sul, with 100 filings and 424 accesses. We can see that in general the largest concentration of filing companies that accessed the Lei do Bem is in the South and Southeast regions of Brazil.

For the other regions, most companies that accessed tax incentives did not file patents during the period studied. In the Midwest, only companies from the Federal District filed patents in the INPI database. In the Northeast, companies from the states of Ceará, Bahia, and Pernambuco filed some type of innovation patent; and for the North region, no company benefitting from Lei do Bem registered patents in the period analyzed (Table 4).

Figure 2. Number of companies benefited by the Lei do Bem that filed patents and the number of accesses, in years - 2006 to 2015, according to State.

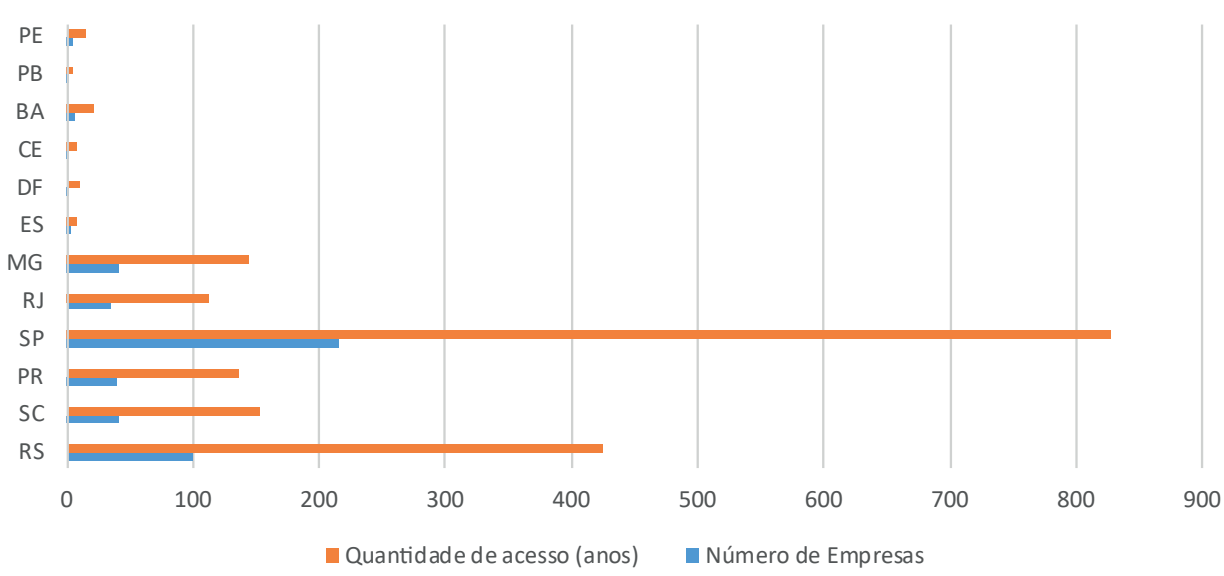

Source: Author's elaboration. 
Felippe Clemente

Table 4.

Average of patent filings, by State, by companies benefitting from the Lei do Bem in the period from 2006 to 2015

\begin{tabular}{|c|c|c|c|c|c|}
\hline \multicolumn{2}{|c|}{ South } & \multicolumn{2}{|c|}{ Northeast } & \multicolumn{2}{|c|}{ North } \\
\hline RS & 4.24 & MA & 0.00 & AM & 0.00 \\
\hline SC & 3.73 & PI & 0.00 & $\mathrm{AC}$ & 0.00 \\
\hline PR & 3.38 & $\mathrm{CE}$ & 8.00 & $\mathrm{RR}$ & 0.00 \\
\hline \multicolumn{2}{|c|}{ Southeast } & $\mathrm{BA}$ & 3.67 & RO & 0.00 \\
\hline SP & 3.85 & $\mathrm{RN}$ & 0.00 & PA & 0.00 \\
\hline $\mathrm{RJ}$ & 3.20 & PB & 4.00 & $\mathrm{AP}$ & 0.00 \\
\hline MG & 3.51 & $\mathrm{PE}$ & 3.75 & & \\
\hline ES & 2.67 & $\mathrm{AL}$ & 0.00 & & \\
\hline \multicolumn{2}{|c|}{ Midwest } & SE & 0.00 & & \\
\hline GO & 0.00 & TO & 0.00 & & \\
\hline MT & 0.00 & & & & \\
\hline MS & 0.00 & & & & \\
\hline DF & 5.00 & & & & \\
\hline
\end{tabular}

Source: Author's elaboration.

In this context, the World Intellectual Property Organization (WIPO) compared the number of patents filed and the degree of innovation of a country and found that there is a strong positive correlation between the two variables. In addition, the publication showed that the number of valid patents in Brazil is behind countries considered a reference in innovation. The survey uses data from 2012 and places the United States first, with 2.2 million patents, followed by Japan, which has 1.6 million. Then China $(875,000)$, South Korea $(738,000)$, Germany $(549,000)$, France $(490,000)$, and the United Kingdom $(459,000)$. Brazil ranked 19 th with 41,453 valid patents. In the BRICS bloc, all are superior in patent filing: following China are Russia $(181,000)$, South Africa $(112,000)$, and India $(42,991)$ (WIPO, 2014).

Figure 3 shows the information on the number of patents filed according to the State. In total, we filed 4,857 patents with INPI between 2006 and 2015 by companies benefiting from the Lei do Bem. The State of São Paulo had the largest number of filings (2,397 in total), representing $49.35 \%$ of patents filed at the national level. The second State with the highest number of patents was Rio Grande do Sul (RS), with 829 patents (17.06\%). The other Brazilian States deposited 1,631 patents or $33.58 \%$ of the total, in the period analyzed. 
Analysis of the Brazilian tax incentives to innovation and patent data: a Principal-Agent model approach

Figure 3. Number of patents filed - 2006 to 2015, according to State.

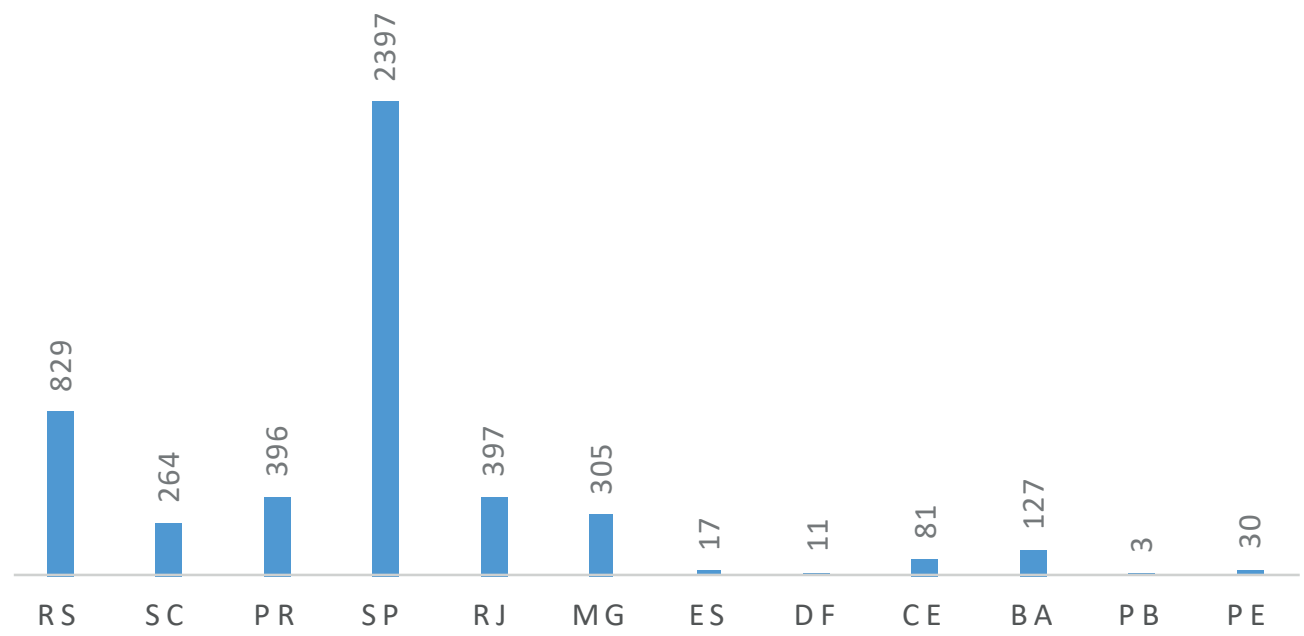

Source: Author's elaboration.

When comparing the regions (Table 5) the concentration in issuance and innovation patent or process filings becomes even more evident. The Southeast region deposited a total of 3,166 patents in the period from 2006 to 2015 , or $64.15 \%$ of the national total. The South region deposited 1,489 patents or $30.65 \%$ of the total. Together, they account for $94.8 \%$ of the total patents of companies benefitting from the Lei do Bem.

Table 5.

Patent filings, according to Region, by companies benefitting from the Lei do Bem in the period from 2006 to 2015

\begin{tabular}{|c|c|}
\hline Region & Patents filed \\
\hline South & 1,489 \\
\hline Southeast & 3,116 \\
\hline Midwest & 11 \\
\hline Northeast & 241 \\
\hline North & 0 \\
\hline Total & 4,857 \\
\hline
\end{tabular}

Source: Author's elaboration. 
Felippe Clemente

Table 6 summarizes the information discussed so far. In general, we can see that the companies benefiting from the Lei do Bem performed innovations of products and processes in the form of patents filed. However, the number of companies benefitting, the number of accesses, and the patents were concentrated in regions which, before Lei do Bem, had traditionally been innovating. The companies located in the regions that should benefit most from the tax exemptions to innovate, namely the North, Northeast, and Midwest, almost did not access the Lei do Bem and so they did not file patents, which evidences the needs for changes to the law so that it can better serve those regions.

Table 6.

Number of companies benefited by the Lei do Bem, number of accesses and patent filings, State, from 2006 to 2015

\begin{tabular}{|c|c|c|c|c|c|c|}
\hline & RS & SC & PR & SP & RJ & MG \\
\hline Number of Companies & 100 & 41 & 40 & 215 & 35 & 41 \\
\hline Quantity of acesses (years) & 424 & 153 & 135 & 827 & 112 & 144 \\
\hline Patents Filed & 829 & 264 & 396 & 2397 & 397 & 305 \\
\hline & DF & CE & BA & PB & PE & ES \\
\hline Number of Companies & 2 & 1 & 6 & 1 & 4 & 3 \\
\hline Quantity of acesses (years) & 10 & 8 & 22 & 4 & 15 & 8 \\
\hline Patents Filed & 11 & 81 & 127 & 3 & 30 & 17 \\
\hline
\end{tabular}

Source: Author's elaboration.

Regarding the total value of the tax benefits granted to companies that accessed the Lei do Bem from 2006 to 2015 (Table 7), we highlight that the Southeast region concentrates a large part of the tax exemption related to innovation activities (80.10\%), followed by the South region (14.37\%). In addition, almost all of the resources allocated to incentives for patent deposits went to the States of São Paulo, Rio de Janeiro, Minas Gerais, and Espírito Santo (84.06\%). The South region received $15.54 \%$ of incentives to file patents or registrations and the Northeast only $0.0038 \%$.

\section{Application of the principal-agent model without incentives}

The applied Principal-Agent model is restricted to companies that have accessed the Lei do Bem from 2006 to 2015. The government, which grants the tax benefits, is interested in the company promoting product or process innovation to increase its competitiveness and increase its productivity, in addition to filing patents with the 
INPI patent bank. However, for this to be possible, the benefitting company (Agent) needs to make efforts in the innovative process and to be "lucky", that is, it depends on the effort made by the companies as well as random (states of nature) and structural factors, such as economic performance. As the Agent seeks to maximize its utility, it is only willing to act according to what the Principal establishes if there are incentives in the execution of the activities. A simplifying hypothesis is to establish two levels of effort: the company benefitting from the Lei do Bem can choose between making high or low effort to promote innovation in the industry. In addition, we have the value known as utility reserve, which is independent of the effort of the company to follow the recommendations in innovation. Therefore, the utility of the company to consider is 0 , as there is no tax exemption for companies that do not access Lei do Bem. To determine whether or not to access the Lei do Bem, the company will compare the gains and its utility reserves, that is, what it earns if it does not access tax incentives.

Table 7.

Tax benefits and incentives for patents granted to companies that accessed the Lei do Bem, according to Region, from 2006 to 2015

\begin{tabular}{|c|c|c|c|c|}
\hline & \multicolumn{2}{|r|}{ Tax Benefits } & \multicolumn{2}{|c|}{$\begin{array}{c}\text { Incentive per } \\
\text { Patent/Registration }\end{array}$} \\
\hline North & $\mathrm{R} \$$ & $31,420,803.44$ & $\mathrm{R} \$$ & - \\
\hline Northeast & $\mathrm{R} \$$ & $31,552,965.35$ & $\mathrm{R} \$$ & $24,211.11$ \\
\hline Midwest & $\mathrm{R} \$$ & $7,902,337.02$ & $\mathrm{R} \$$ & - \\
\hline Southeast & $\mathrm{R} \$$ & $1,027,710,238.81$ & $\mathrm{R} \$$ & $5,268,453.42$ \\
\hline South & & $184,405,811.81$ & $\mathrm{R} \$$ & $974,091.11$ \\
\hline
\end{tabular}

Source: Author's elaboration.

For companies that access the Lei do Bem and promote the high effort, that is, innovate and also file patents with the INPI patent bank, the multiplier effect of incentives to innovation is considered as $4.4,{ }^{16}$ that is, for each 1 real in incentive, companies invest 4.4 reais. This occurs in the case of the phenomena of nature being favourable, given the agent's effort. Thus, the hypothesis is that, with effort, the company will obtain the total tax exemption and, through the multiplier effect, will have its revenue. Profit is obtained by deducting the cost of filing patents from the revenue. ${ }^{17}$ In this hypothesis, it is deemed that, with luck, about $87 \%{ }^{18}$ of the

16 Data from the Ministry of Science, Technology, Innovation and Trade (MCTIC).

17 See: Kagan Binder, PLLC, 2004.

18 Data from the Annual Industrial Survey of Companies (PIA-Empresas) of the Brazilian Institute of Geography and Statistics (IBGE), fall in investments in times of crisis of approximately 13\%, 2015. 
Felippe Clemente

volume invested can be realized for the two levels of effort chosen. In other words, it considers a $13 \%$ drop in the multiplier effect of fiscal incentives for periods of economic downturn. With "luck", we work with an optimistic view that $100 \%$ of the multiplier effect is applied to the volume of incentives granted to companies.

To facilitate the analysis, we prepared the games taking into account the characteristics of each Brazilian region. Thus, Figure 5 represents the game tree for the Southeast region, which indicates the possible actions of the Company (Agent) and Government (Principal), and the payoffs, results in financial terms for both.

If companies in the Southeast region choose to make a high effort (action a1, node $\mathrm{t}_{3}$ ) and are lucky (action s, node $\mathrm{t} 4$ ), revenue will be 100\% materialized in fixed assets, totaling $\mathrm{R} \$ 4,521,925,050.76 .{ }^{19}$ As in the high effort, the company performs innovation and files the patent, the costs of maintenance of the patents are debited in public agencies (National Institute of Industrial Property - INPI). Given that companies in the Southeast region that accessed the Lei do Bem filed 3,116 patents in the period from 2006 to 2015 and that the cost of maintaining a patent in Brazil is $\mathrm{R} \$ 33.463,10,{ }^{20}$ it is estimated that the cost of patents for the Southeast region is $\mathrm{R} \$ 104,271,019.60$. Subtracting these costs from corporate revenues, we have a net value of $\mathrm{R} \$ 4,417,654,031.16$. In this ramification of the game, the government has a social cost with companies for $\mathrm{R} \$ 923,439,219.20$, which corresponds to the number of tax incentives granted to companies in the region in the period from 2006 to $2015(\mathrm{R} \$ 1,027,710,238.81$ ) subtracted from the value of the patent filed by the companies to the public agency (R\$104,271,019.60). If companies apply a lot of effort but have bad luck, they will receive revenue of $87 \%$ of the tax benefits fixed assets. Therefore, this amount will correspond to $\mathrm{R} \$ 3,934,074,794.00$. Subtracting the cost of patent deposits ( $\mathrm{R} \$ 104,271,019.60)$, the companies will have a net revenue of $\mathrm{R} \$ 3,829,803,774.00$. The social cost of government remains the same in this part of the game, as tax exemptions are granted regardless of the economic performance of companies. Considering now that the companies benefitting from the Lei do Bem apply low effort, that is, innovate, but do not file patents with INPI, and they are lucky, ${ }^{21}$ they will have revenue of $\mathrm{R} \$ 4,521,925,050.76$ without deduction of any cost because there is no patent issued. In this case, the social cost of the government will be identical to the tax exemptions granted to companies in the Southeast, or $\mathrm{R} \$ 1,027,710,238.81$. Similarly, when companies apply low effort and have bad luck, the actual revenue is $87 \%$, which produces a profit of $\mathrm{R} \$ 3,934,074,794.00$ without deduction of the cost of patents,

19 The multiplier effect of 4.4 multiplied by the total tax incentives in the Southeast region $(\mathrm{R} \$ 1,027,710,238.81)$

20 Cost in dollars: $\$ 10,490$ and the dollar exchange rate for July 14,2017 : $\mathrm{R} \$ 3.19$

21 Considering the multiplier of 4.4.

Revista Finanzas y Politíca Económica, Vol. 13, N.ํ2, julio-diciembre, 2021, pp. 403-437 
Analysis of the Brazilian tax incentives to innovation and patent data: a Principal-Agent model approach

since they have not been filed. The social cost of government remains the same for the case of low effort because the tax benefit does not depend on the economic performance of the sectors to be released.

In this way, the solution to the game can be found using perfect subgame equilibrium, that is, solving by reverse induction. Substituting the last lottery of Figure 4, corresponding to the possible states of nature, by their expected values, we move to node $t_{3}$, where the companies benefitting from the Lei do Bem will decide between the two possible actions to be performed: high or low effort.

Figure 4. Principal-Agent game without incentives for patents involving companies in the Southeast region benefitting from the Lei do Bem and government

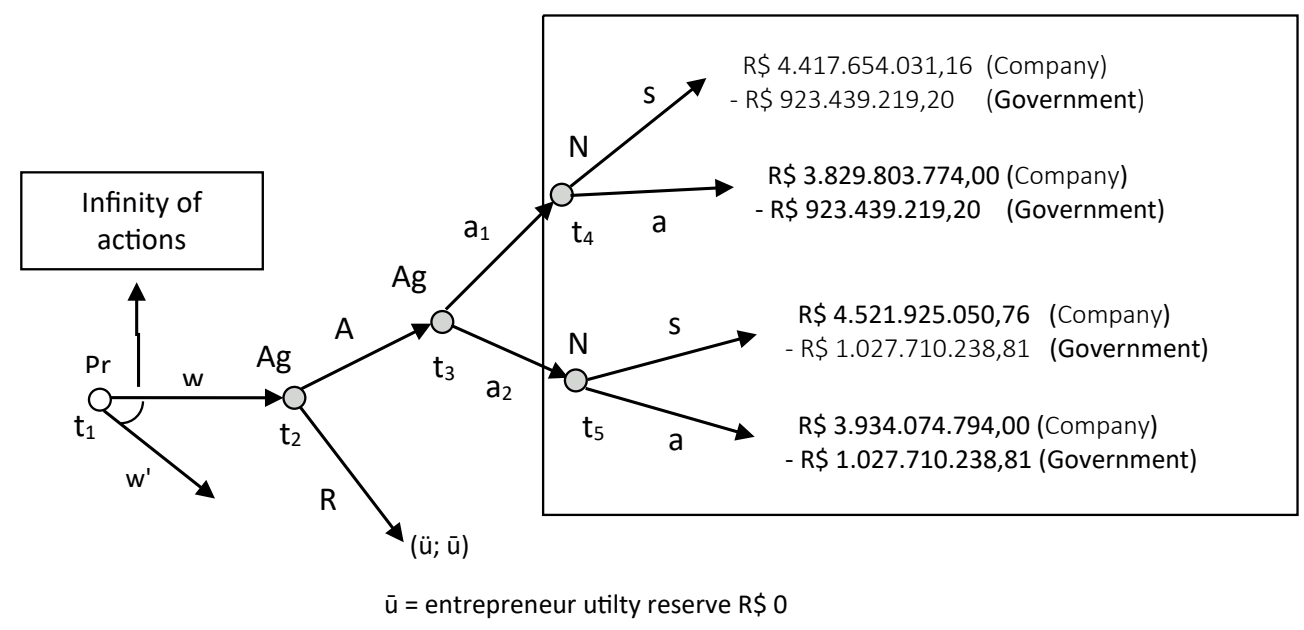

Source: Author's elaboration.

At this point, companies compare the expected utilities for the two cases, analyzing the difference in revenue of the two alternatives, and thus decide the level of effort they will employ, i.e., which maximizes utility. In fact, companies will buy the utility provided by the two possible actions they can take, given the two expected revenues according to the states of nature and their respective efforts, that is, they compare the utility of applying high effort, $\mathrm{u}(\mathrm{p}(\mathrm{s}) * 4,417,654,031.16+\mathrm{p}(\mathrm{a}) * 3,829,803,774.00$, a1), with the utility of applying low effort, $\mathrm{u}(\mathrm{p}(\mathrm{s}) * 4,521,925,050.76+\mathrm{p}(\mathrm{a}) * 3,934,074,794.00, \mathrm{a} 2)$. The companies will decide to apply high effort, that is, they will file patents, if they attribute to the difference of effort a value less than or equal to the difference between the proceeds of applying such efforts. Revenues, in turn, will depend directly on the probability 
Felippe Clemente

of each of the states of nature. In this case, in the best scenario, if companies are lucky with a $100 \%$ chance $(\mathrm{p}(\mathrm{s})=1)$, the difference between applying high and low effort is -R\$104,271,019.60, which represents a significant value for companies in the Southeast region. Thus, the choice of the application of low effort becomes justifiable, since the companies do not receive tax exemption for the effort expended, that is, to file patents.

After deciding on low effort, companies move to node $t_{2}$ where they will decide whether to accept or reject the government's tax incentive proposal. They will accept it only if the expected utility of the chosen action is greater than or equal to the expected utility of the other possible options, that is, the level of companies' utility reserve, respecting the restriction of participation. The companies receive nothing $(\overline{\mathrm{u}}=0)$ in terms of utility reserve if they refuse to participate in the system of tax benefits proposed by the Lei do Bem. With this income, in $\mathrm{t}_{2}$, following the theoretical model, companies accept access to tax benefits as, in the worst case, the profit, with the Lei do Bem, for the state of nature of bad luck is $\mathrm{R} \$ 3,934,074,794.00$, which is much higher than the value of the utility reserve stipulated in this study. In $\mathrm{t} 1$, the government chooses to promulgate the instrument to incentive innovation, in this case, the Lei do Bem, or otherwise.

The question is whether the enacted law is appropriate for each of the types of innovative companies. Thus we see the differences in gains (or social cost) of the government for each state of nature. If the state is "lucky", the government can benefit $\mathrm{R} \$ 104,271,019.61$ should the companies apply high effort. The same value occurs for the "bad luck" state. This value corresponds to how much the government or innovation incentive bodies could pay more for the effort of companies to innovate and patent the innovation.

Figure 5 shows the "payoffs" of the companies benefitting from the Lei do Bem and the government of the South region of Brazil. In the period from 2006 to 2015, 1,489 patents were filed with the INPI patent bank by companies located in the states of Rio Grande do Sul, Santa Catarina, and Paraná. Given that the cost of maintaining patents in Brazil, according to Kagan Binder (2004), is $\mathrm{R} \$ 33,463.10$, we estimated that the total cost of patents in the South region is $\mathrm{R} \$ 184,405,811.81$. We debited this amount from corporate revenue in the event of high effort, either "luck" or "bad luck" and credited to government accounts, also in the two states of nature. In the case of low effort by companies benefiting from tax incentives, we considered only the amounts of tax exemptions.

Thus, in solving the game using reverse induction, the model encouraged companies to exercise low effort in the domain of innovation/patent registration, considering the high cost of maintaining these registrations. It was found that 
Analysis of the Brazilian tax incentives to innovation and patent data: a Principal-Agent model approach

companies agree to participate in the Lei do Bem, but do not receive any other incentive or premium to register patents arising from the innovation made. The same result is shown for Figures 6 and 7, which show values for the Midwest (total patent cost $R \$ 368,094.10$ ) and Northeast (total patent cost $R \$ 8,064,607.10$ ), respectively.

Figure 5. Principal-Agent game without incentives for patents involving companies in the South region benefitting from the Lei do Bem and government

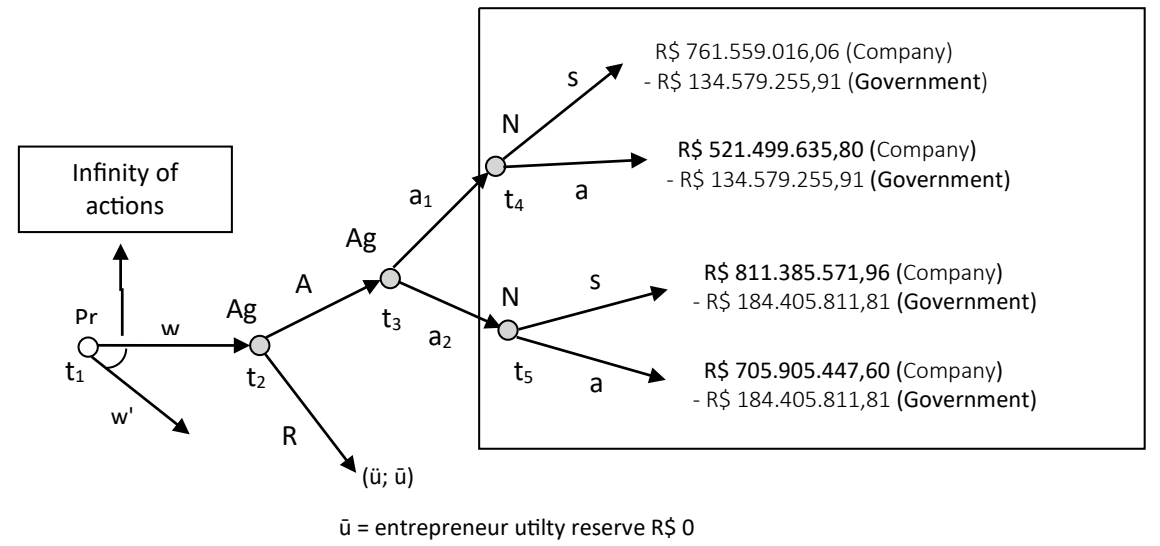

Source: Author's elaboration.

Figure 6. Principal-Agent game without incentives for patents involving companies in the Midwest region benefitting from the Lei do Bem and government

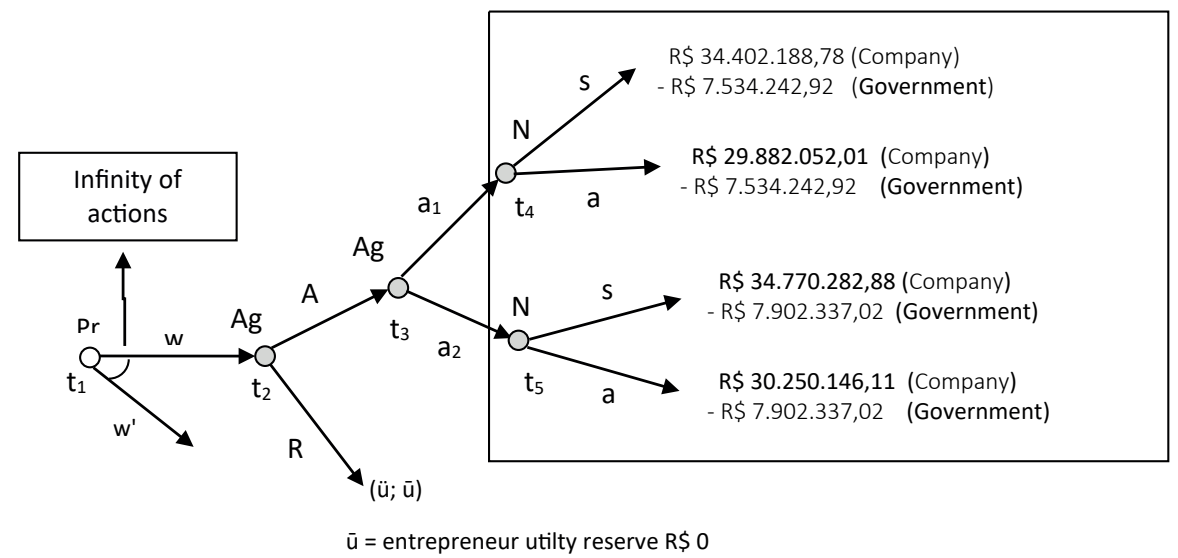

Source: Author's elaboration. 
Felippe Clemente

Figure 7. Principal-Agent game without incentives for patents involving companies in the Northeast region benefiting from the Lei do Bem and government

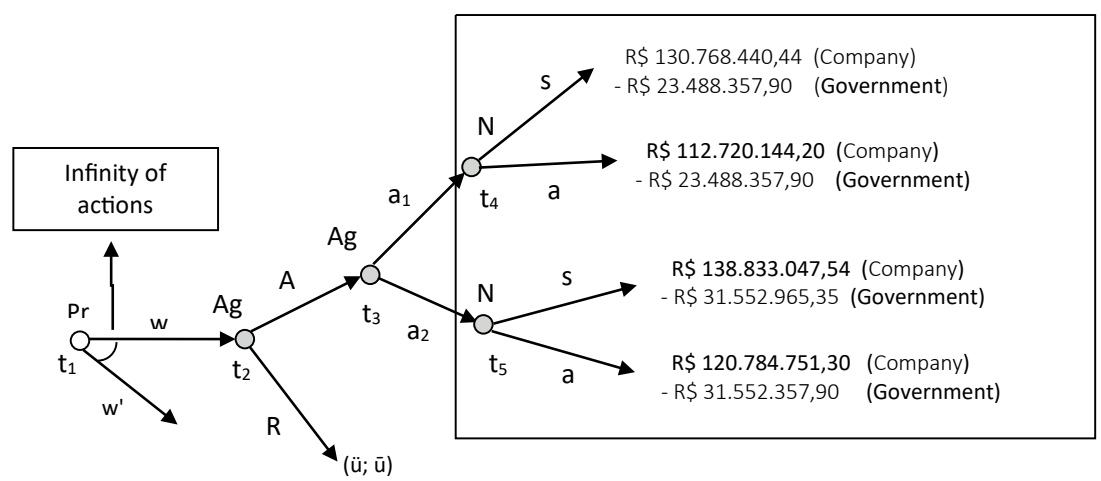

Source: Author's elaboration.

For the Northern region (Figure 8), corporate and government "payoffs" are the same for both high and low effort. This is because, in the period from 2006 to 2015, no patent was filed with INPI from companies located in the northern region of Brazil. In this case, we considered only the ramification of the game indicating low effort, evidencing the same path travelled by companies in the north. That is, companies agree to participate in the tax benefits granted by the Lei do Bem, but they are not stimulated or encouraged to expend high effort in registering and maintaining patents.

Figure 8. Principal-Agent game without incentives for patents involving companies in the North region benefitting from the Lei do Bem and government

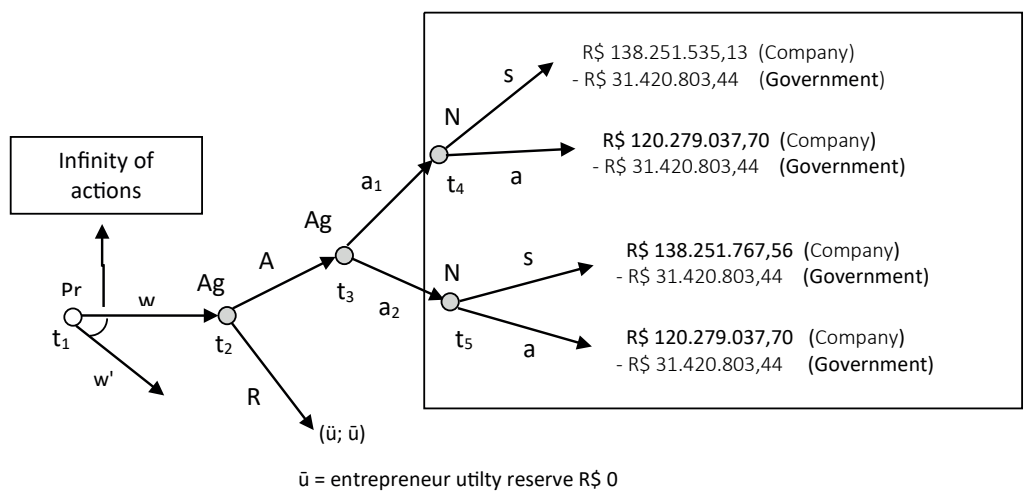

Source: Author's elaboration. 
In general, we can see that companies, in all regions in Brazil, make a low effort when considering innovation involving the registration of marks and patents. Once again, we can see that the high cost of maintaining patents with public agencies makes it difficult for companies to make their innovations available in the database. For policymakers, it is important to highlight the need for some efficient mechanism in the Lei do Bem to encourage the publication of patents, to encourage companies to patent their innovation activities.

Given the application, we can observe that the incentives contained in the Lei do Bem and proposed by the government do not encourage companies to make a high effort, i.e. innovate and register patents in the INPI database. We noted an advantage for companies to access the Lei do Bem to benefit from tax incentives, as they always get more than the utility reserve. However, the law does not have mechanisms that encourage companies to make a high effort. What happens is that the cost of patents and their maintenance is much higher than that in developing countries. According to Kagan Binder (2004), patent costs in Brazil amount to $\$ 10,490.00$. This value resembles the values of developed countries such as France $(\$ 11,750.00)$, Spain $(\$$ $12,335.00)$, and Italy $(\$ 12,970.00)$. Other developed countries have lower costs than Brazil, such as the United States $(\$ 8,550.00)$ and Canada $(\$ 7,255.00)$. Developing countries have much lower costs because they have the purpose of encouraging innovation in their territory, which is still incipient. South Africa (\$2375.00) and New Zealand ( $\$ 2105.00$ ) are countries with low costs in filing patents, encouraging companies to register their innovations.

It is worth mentioning that the $87 \%$ percentage stipulated for the fall in economic performance, with the "bad luck" state of nature, may have been undersized, or that the revenues stipulated when a high effort is made have been unrealistic. However, the need for real incentives for companies to register innovations is evident.

\section{Application of the principal-agent model with incentives}

The analysis of this section concerns the investigation of the incentive mechanism in the Lei do Bem for filing/registering patents in the INPI database. According to Table 7, from 2006 to 2015, some Brazilian regions received incentives for patent registrations. Thus, we considered these incentives on Figures 9, 10, and 11 for the Southeast, South, and Northeast regions, respectively. For all three regions, the payoffs of companies increased if they proposed to make a high effort. However, due to the negligible value granted by public agencies to companies that have filed patents, 
the retroactive solution of the games indicates that it is still more advantageous to make a low effort on the part of companies benefitting from the Lei do Bem in the regions analysed.

Thus, for incentives to exert a stimulus on companies to make a high effort, the government must reimpose the granting of tax benefits, giving more emphasis to incentives that include the registration and filing of patents. For the Southeast region, considering the "luck" state of nature, the incentives for patent filing should be at least $\mathrm{R} \$ 99,002,566.18$ for companies to make a high effort and record their innovations in the INPI database. For the South region, with the same state of nature, the necessary incentives for the choice of high effort by the beneficiary companies are of the order of at least $\mathrm{R} \$ 48,852,464.79$. For the Northeast region, this amount must be at least $\mathrm{R} \$ 8,040,395.99$. With these incentives to register/file patents, companies in these regions would be encouraged to make high efforts and register patents in public agencies responsible for innovation in Brazil. For the government, this kind of tax exemption would be more interesting, since part of the benefit returns to the public sector in the form of annuities and patent filing fees, in addition, to show, more transparently and accurately, how the Brazilian innovation system has improved and evolved.

Figure 9. Principal-Agent game with incentives for patents involving companies in the Southeast region benefitting from the Lei do Bem and government

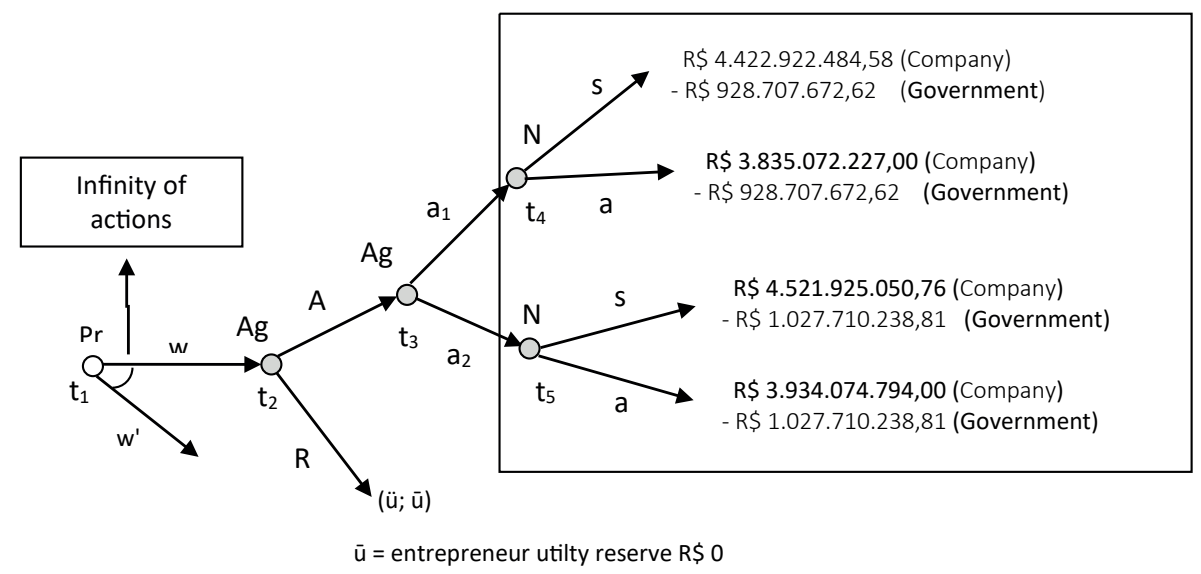

Source: Author's elaboration. 
Analysis of the Brazilian tax incentives to innovation and patent data: a Principal-Agent model approach

Figure 10. Principal-Agent game with incentives for patents involving companies in the South region benefitting from the Lei do Bem and government

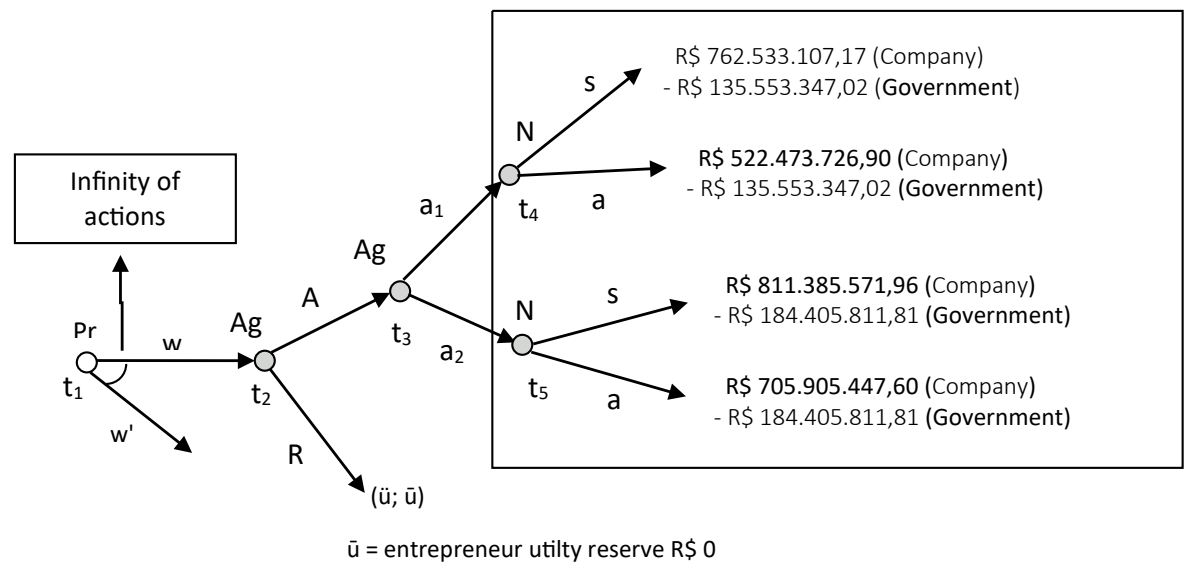

Source: Author's elaboration.

Figure 11. Principal-Agent game with incentives for patents involving companies in the Northeast region benefitting from the Lei do Bem and government

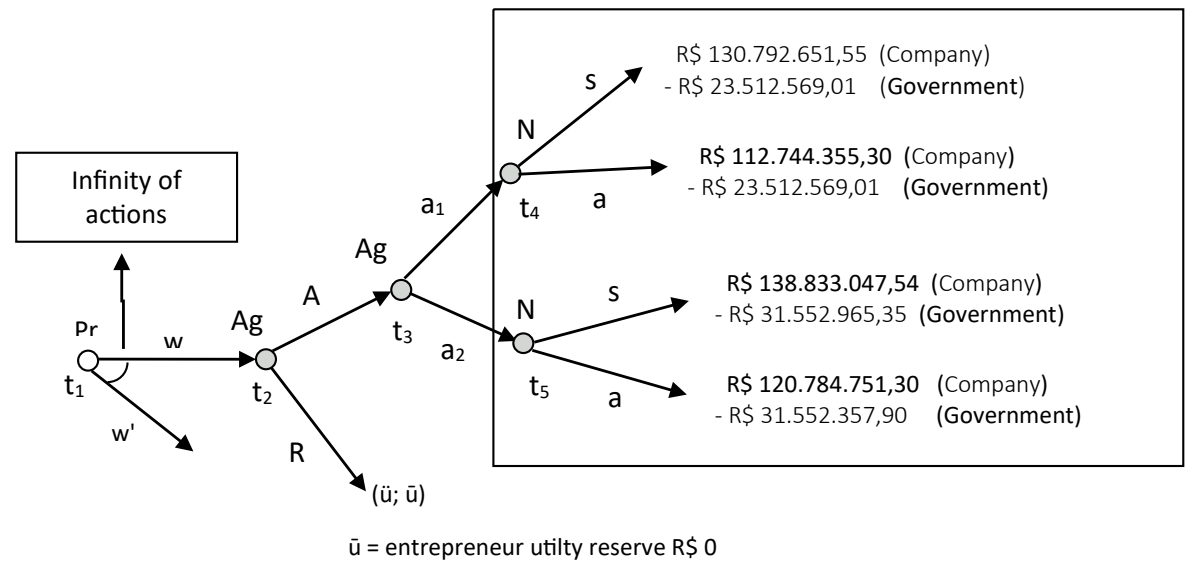

Source: Author's elaboration. 
Felippe Clemente

\section{CONCLUSIONS}

This study found empirical results on the moral hazard in the Brazilian system of innovations, specifically the Lei do Bem. We emphasized as main results the low effort made by companies benefitting from the tax exemptions of the Lei do Bem and the lack of effective incentive for companies to file patents and maintain their innovations in the INPI database. Other significant result is that, even with the incentive granted by the government to companies in the Southeast, South, and Northeast for patents, it is still rational for companies in these regions to make low innovation efforts. This can lead to a discussion how the public decision makers should effectively monitor companies, based on proxies that objectively present the level of effort of the agent. In this sense, creating mechanisms in the Lei do Bem that value innovative companies more which patent more products can be a good way of revealing the real effort of the agent (companies) in relation to what is proposed by the principal (government). Another way can come through support and tax incentives for the post-patent period, in which the new product and/or technology need to expand in scale until reaching final consumers.

However, it is necessary to consider that the linked incentive related to the filing of a patent is also a spasmodic response to a more complex problem, related to the low innovative activity in Brazil, which in the last few years has been undergoing in a process of deindustrialization. In this line, rethink another national plan for growth taking into account all Brazilian industries and their capacity to produce new technologies is essential and as important as new measures that increase incentives to patent products. Patents are the end product of an innovation chain and come as a consequence of a good and structured industrial policy.

The article contributes to the literature because it is the first empirical study that uses data from reports about companies benefitting from the Lei do Bem provided by the Ministry of Science, Technology, and Innovation (MCTI) and the patents filed by these companies in the database of the National Institute of Intellectual Property (INPI) in the period in which the Law has been in effect. This fills, in part, the gaps in the practical field for studies dealing with innovation in Brazil.

One of the limitations of this study may be the fact of taking into account underestimated simulations for the cases of economic performance and also of the 
efforts made by the companies. Although the information is limited, improving the percentages of the scenarios.

Given this evidence, it is worth discussing ways to improve tax incentives. As knowledge of incentives increases and gains in expertise in obtaining them increase, it is important to pay attention to intensifying their use. In addition, it is necessary to think about future changes in the law to preserve the incentive as its returns diminish. As a suggestion, it is important to think about utilization rules based on the increment in R\&D expenditures, instead of the tax exemption based on the total expenditures made, or variations in the determinants of the cost of capital use. That is, always discuss improvement alternatives to avoid its exhaustion.

\section{ACKNOWLEDGEMENTS}

The author would like to thank Departamento de Economia and Departamento de Economia Rural, Universidade Federal de Viçosa, Brazil for their cooperation and precious help during the research development.

\section{CONFLICT OF INTEREST STATEMENT}

The work is original and has not been published elsewhere in any form or language (partially or in full). Material preparation, data collection and analysis were performed by Felippe Clemente and researchers commented on previous versions of the work. The author certifies that they have no potential conflict of interest in this manuscript.

\section{REFERENCES}

1. Akerlof, George A. (1970). The Market for 'Lemons': Quality, Uncertainty, and the Market Mechanism, Quarterly Journal of Economics 84: 488-500.

2. Alam, Pervaiz; KAREN, Schuele Walton. (1995). Information Asymmetry and Valuation Effects of Debt Financing, Financial Review 30(2): 289-311.

3. Albuquerque, E. M. (1996) Sistema nacional de inovação no Brasil: uma análise introdutória a partir de dados disponíveis sobre a ciência e a tecnologia. Revista de Economia Política, 16(3) (63), julho-setembro. 
4. Andersen, E.S. et al. (2002) Editorial, special issue, Innovation Systems. Research Policy, 31(2), p. 185-190.

5. Anpei - Associação Nacional de Pesquisa e Desenvolvimento das Empresas Inovadoras (2017) Contribuições ANPEI para aprimoramentos no capítulo III da Lei nº 11.196/05, Lei do Bem, Comitê de Fomento ANPEI, São Paulo.

6. Anton, J. J.; Yao, D. A. (2002). The sale of Ideas: strategic disclosure, property rights, and contracting. Review of Economic Studies, 69, 513-531.

7. Araújo, B. C. (2009) Incentivos fiscais à pesquisa e desenvolvimento e custos de inovação no Brasil. Radar Dieset, Instituto de Pesquisa em Economia Aplicada (IPEA), Rio de Janeiro, 9.

8. Avellar, A. P. M. (2009) Impacto das políticas de fomento à inovação no Brasil sobre o gasto em atividades inovativas e em atividades de P\&D das empresas. Revista Estudos Econômicos, 39(3), p. 629-649.

9. Avellar, A. P. M.; Botelho, M. R. A. (2016) Efeitos das políticas de inovação nos gastos com atividades inovativas das pequenas empresas brasileiras. Revista Estudos Econômicos, 46(3), p. 609-642.

10. Barbosa, E.; Gourlart, L. Rocha, M. C.; Pimenta, R. (2013) Incentivos fiscais internacionais para P\&D. Inventta - Financial Resources for Technological Innovation. 32p.

11. Bhattacharya, S., Ritter, J.R. (1983). Innovation and Communication: Signaling with Partial Disclosure, Review of Economic Studies L, 331-46.

12. Blind, K.; Pohlischa, J.; ZI, A. (2018) Publishing, patenting, and standardization: Motives and barriers of scientists. Research Policy 47 1185-1197.

13. Cho, Shin. (1992). Agency Costs, Management Stockholding, and Research and Development Expenditures, Seoul Journal of Economics 5(2): 127-52.

14. Clemente, F.; Da Silva, E. H. (2017) The Principal-Agent Model with Moral Hazard in the Brazilian Innovation System: The Case of 'Lei do Bem'. World Academy of Science, Engineering and Technology, International Journal of Economics and Management Engineering 11(8), available on: https://publications.waset.org/abstracts/66837/pdf

15. Clemente, F.; Silva Júnior, A. (2012) Contratos entre produtores de soja da agricultura familiar e indústria de biodiesel: uma aplicação do modelo Principal-Agente. Estudo, Sociedade e Agricultura, 20 (2), 509-527.

16. Clemente, F; Silva Júnior, A. (2013) Contracts between Small Scale Soybean Farmers and the Biodiesel Industry in Brazil: An Application of Principal-Agent Model. Proceedings of the $6^{\text {th }}$ International European Forum on System Dynamics and Innovation in Food Networks, International Center for Food Chain and Network Research, University of Bonn, Germany, February 18-22, Innsbruck-Igls, Austria, available on: https:// ageconsearch.umn.edu/record/164767? ln =en

17. Cni - Confederação Nacional da Indústria (2017) Indústria Brasileira. Revista da Confederação Nacional da Indústria, 2 (18). 
Analysis of the Brazilian tax incentives to innovation and patent data: a Principal-Agent model approach

18. Cohen, W. M.; Levin, R.C. (1989) Empirical studies of innovation and Market structure. In schmalensee, R. \& Willig, R. D., ed. Handbook of Industrial Organization, Amsterdam, Elsevier Science, 2: pp. 1.059-107.

19. Corder, S. (2006) Políticas de inovação tecnológica no Brasil: experiência recente e perspectivas. Brasília: IPEA. (Texto para Discussão, n. 1244).

20. Costa, D. R. M. (2008) Moral Hazard na relação contratual entre Cooperativa e Cooperado. Revista de Contabilidade e Organizações (RCO) - FEARP/USP, 2(4), p.55-74.

21. Delreux, T.; Adriaensen, J. (2017) The Principal Agent Model and the European Union, Palgrave Studies in European Union Politics, doi 10.1007/978-3-319-55137-1_1

22. Eng, Li Li, and Margaret Shackell. (2001). The Implications of Long Term Performance Plans and Institutional Ownership for Firms' Research and Development Investments, Journal of Accounting, Auditing and Finance 16(2): 117-39

23. European Comission (2016) Patent costs and impact on innovation. Research and Innovation, Brussels, 138p .

24. Francis, Jennifer; Abbie, Smith. (1995). Agency Costs and Innovation: Some Empirical Evidence, Journal of Accounting and Economics 19(2/3): 383-409.

25. Freeman, C. (1982) The economics of industrial innovation. 2. ed. London: Frances Pinter.

26. Griliches, Z. (1990) Patent statistics as economic indicators: a survey. Journal of Economic Literature, 28(4), pp. 1.661-707.

27. Hall, B. H.; Lerner, J. (2009) The Financing of R\&D and Innovation. NBER Working Paper No. 15325. 56p.

28. IBGE - Instituto Brasileiro de Geografia e Estatística (2015) Pesquisa Industrial Annual - Empresas (PIA-Empresas). 34(1), p.1-74.

29. Jensen, Michael C., and William Meckling. (1976). Theory of the Firm: Managerial Behavior, Agency Costs, and Ownership Structure, Journal of Financial Economics 3: $305-60$.

30. Johnson, Mark S., and Rajesh P. Rao. (1997). The Impact of Antitakeover Amendments on Corporate Financial Performance, Financial Review 32 (4): 659-89.

31. Kagan Binder, PLLC (2004) Estimated Patent Cost: National and International. Suite 200, Maple Island Building, 221 Main Street North Stillwater, MN 55082

32. Kannebley junior, S.; Porto, G. S.; Pazello, E. T. Inovação na indústria brasileira: uma análise exploratória a partir da PINTEC. Revista Brasileira de Inovação, 3(1), jan-jun 2004.

33. Kannebley Junior, S., Shimada, E., De Negri, F. (2016) Efetividade da Lei do Bem no Estímulo aos Dispêndios em P\&D: uma análise com dados em painel. Pesquisa e Planejamento Econômico (PPE), 46(3). 
34. Laffont, J.; Martimort, D. (2002) The theory of incentives: the principal-agent model. Princeton, EUA: Princeton University Press.

35. Leland, Haynes E., and David H. Pyle. (1977). Informational Asymmetries, Financial Structure, and Financial Intermediation, Journal of Finance 32: 371-87.

36. Majurmdar, Summit K., and Amerada Nagarajan. (1997). The Impact of Changing Stock Ownership Patterns in the United States: Theoretical Implications and Some Evidence, Revue d'Economie Industrielle 82: 39-54.

37. Mass-collel, A.; Whinston, M. D.; Green, J. (1995) Microeconomic Theory. New York, Oxford University Press.

38. Matesco, V. R.; Tafner, P. (1998) O estímulo aos investimentos tecnológicos: o impacto sobre as empresas brasileiras. Rio de Janeiro: Ipea, (Texto para discussão, n. 429).

39. Ministério da Ciência, Tecnologia, Inovação e Comunicações - MCTIC (2014) Relatório Anual de incentivos fiscais. Brasília, DF, 86p.

40. Nascimento, A. P. (2007) A Eficácia dos contratos de serviços a por pregão. Dissertação (Mestre em Ciências Contábeis). FUCAPE. Vitória, ES. 107p.

41. Pereira, J. M. (2003) Política de Proteção à Propriedade Intelectual no Brasil. In: ENANPAD, 27, 2003, Rio de Janeiro. Anais... Rio de Janeiro: ANPAD, p. 1-15.

42. Posner, Eric A. (2001) "Cost-benefit analysis as a solution to a Principal-Agent problem.” Administrative Law Review, 53(1), pp. 289-297. JSTOR, JSTOR.

43. Pugh, William N., John S. Jahera, Jr., and Sharon Oswald. (1999). ESOPs, Takeover Protection, and Corporate Decision Making, Journal of Economics and Finance 23(2): 170-83.

44. Salainé, B. (2002) The economics of contracts. Cambridge: The MIT Press.

45. Sampaio, L. M. B. (2007) Modelo principal-agente para contratos entre pequenos produtores e empresas exportadoras de manga no Rio Grande do Norte. RER, 45 (4), p. 879-898, out.

46. Schwartz, A. (1992) Legal theory and incomplete contracts. Contracts Economics, Oxford: Blackwell. 359p.

47. Szewczyk, Samuel H., George P. Tsetsekos, and Zaher Z. Zantout (1996) The Valuation of Corporate R\&D Expenditures: Evidence from Investment Opportunities and Free Cash Flow, Financial Management 25(1): 105-10.

48. Tether, B.S. (2003) What is innovation? Approaches in distinguishing new products and processes from existing products and processes. Center for Research on Innovation Eु Competition (CRIC) Working Paper n. 12. Manchester (RU): The University of Manchester, 29 ago.

49. Turchi, L. M., Moraes, J. M. (2017) Políticas de apoio à inovação tecnológica no Brasil: avanços recentes, limitações e propostas de ações. Brasília: Ipea, 485 p.

50. Varian, H. R. (1999) Intermediate Microeconomics. 5 ed. New York: W.W Norton. 
Analysis of the Brazilian tax incentives to innovation and patent data: a Principal-Agent model approach

51. Wipo - World Intellectual Property Organisation (2014) World Intellectual Property Indicators. Economics and Statistics Division, no. 941 E/14, ISBN 978-92-805-2558-8, Switzerland.

52. Zantout, Zaher Z. (1997). A Test of the Debt Monitoring Hypothesis: The Case of Corporate R\&D Expenditures, Financial Review 32(1): 21-48.

53. Zucoloto, G. F. (2008) A Lei do Bem: impactos das atividades de P\&D no Brasil. Radar Dieset, Instituto de Pesquisa em Economia Aplicada (IPEA), n.6, 9f. 
